\title{
Inclusion of tallow and soybean oil to calf starters fed to dairy calves from birth to four months of age on calf performance and digestion
}

\author{
T. M. Hill, ${ }^{1}$ H. G. Bateman II, ${ }^{2}$ J. M. Aldrich, J. D. Quigley, and R. L. Schlotterbeck \\ Nurture Research Center, Provimi North America, Cargill Premix and Nutrition, Brookville, OH 45309
}

\section{ABSTRACT}

Energy demands for calves can increase during periods of heat and cold stress. One way to potentially increase energy intake is to increase the energy density of the feed with fat. Trial 1a compared a control starter with no added fat or oil (CON) to starters with $2 \%$ tallow (TAL) and $2 \%$ soybean oil (SBO). Starters were $20 \%$ crude protein (CP) and 45 to $47 \%$ starch. Male Holstein calves that were initially 3 to $5 \mathrm{~d}$ of age were fed a $27 \% \mathrm{CP}, 17 \%$ fat milk replacer at $0.66 \mathrm{~kg}$ of dry matter daily and fully weaned by $42 \mathrm{~d}$ of a $56-\mathrm{d}$ trial. Trial $1 \mathrm{~b}$ estimated the digestion of the diets (employed chromic oxide as an indigestible digesta flow marker) using a subset of 5 weaned calves per treatment between d 52 and 56. Trial 2 used Holstein calves initially 59 to $61 \mathrm{~d}$ of age fed starters CON and SBO blended with $5 \%$ chopped grass hay over a 56 -d trial. Trial 3 used Holstein calves initially 59 to $61 \mathrm{~d}$ of age fed starters CON and TAL blended with $5 \%$ chopped grass hay over a 56-d trial. Treatments were compared using repeated measures (where appropriate) in a completely randomized design. In trials $1 \mathrm{a}$ and $1 \mathrm{~b}$, preplanned contrasts compared CON versus TAL and CON versus SBO. Compared with CON, calves fed SBO had reduced starter intake, average daily gain, and digestion of dry matter, organic matter, and $\mathrm{CP}$ before $8 \mathrm{wk}$ of age. Compared with CON, calves fed SBO had reduced average daily gain and change in hip width from 2 to 4 mo of age. Compared with CON, calves fed TAL had reduced average daily gain and tended to have reduced change in hip width from 2 to 4 mo of age. Calculated metabolizable energy intake was not increased in any trial by added fat or oil. Tallow and soybean oil inclusion at $2 \%$ of the starter feed was not advantageous for calf growth before 4 mo of age.

Key words: fat, oil, calf, digestion

Received January 23, 2015.

Accepted March 15, 2015.

${ }^{1}$ Corresponding author: mhill@akey.com

${ }^{2}$ Deceased.

\section{INTRODUCTION}

During periods of heat and cold stress, maintenance energy requirements of calves can increase. Starter intake and digestion in the young calf may be limited due to incomplete rumen development; therefore, it may be useful to increase the energy density of starters with fat. Much of the previous research around adding fat or oil to calf starters has been with calves fed milk and milk replacer (MR) fed at conventional amounts of approximately $450 \mathrm{~g}$ of DM daily. Fallon et al. (1986) reported that adding 5, 10, and 20\% fat from Ca-soaps reduced starter intake and ADG. Caffrey et al. (1988) reported that adding $3.5 \%$ fat to starters reduced starter intake. When $10 \%$ fat was added to starters, starter intake and ADG were reduced versus no added fat (Doppenberg and Palmquist, 1991). Bunting et al. (1996) reported no differences in calf intake or ADG between 0 and $5 \%$ hydrolyzed tallow in starters. Adding roasted soybeans to starters decreased starter intake and ADG in calves less than 2 mo of age when compared with lower-fat starters (Kuehn et al., 1994). Similarly, Hill et al. (2011) reported that soy oil added to starters before 2 mo of age and fed in approximately $0.66 \mathrm{~kg}$ of $\mathrm{MR}$ between 2 and 4 mo of age reduced ADG of calves compared with lower-fat starters. More recently, Araujo et al. (2014) reported that starters with soybeans were useful to provide extra energy and support additional ADG when MR were fed at approximately 0.69 but not 0.46 $\mathrm{kg}$ of DM daily. Their calves fed the high-fat starters had greater digestibilities of CP and fat postweaning compared with calves fed the low-fat starters. The use of oil from soybeans might have a negative effect on the diet because of its high concentration of linoleic acid. This was demonstrated in both the MR and starter trials of Hill et al. (2011). Adding linoleic acid via soybean oil to diets elicited an inflammatory response in calves that contributed to the reduction in ADG.

Our objectives were to further test the addition of either tallow or soybean oil to calf feeds offered to calves from near birth to approximately 4 mo of age. Our hypotheses were that the addition of $2 \%$ fat or oil would not increase measurements of growth or change diet digestibility; whereas higher levels of fat supple- 
mentation would have had a greater chance to decrease calf ADG through reductions in intake and digestion.

\section{MATERIALS AND METHODS}

Calves were cared for by acceptable practices as described in the Guide for the Care and Use of Agricultural Animals in Research and Teaching (FASS, 2010). During the preweaning phase, all calves were fed a $27 \% \mathrm{CP}, 17 \%$ fat MR at $0.66 \mathrm{~kg} / \mathrm{d}$ from 1 to 39 $\mathrm{d}$ in equal meals fed at 0615 and $1530 \mathrm{~h}$, then 0.33 $\mathrm{kg} / \mathrm{d}$ from 40 to $42 \mathrm{~d}$ in 1 meal at $0615 \mathrm{~h}$. This MR was based on whey protein concentrate, whey, and lard as the major fat source similar to the MR 1 in trial 1 of Hill et al. (2011). The MR were diluted to $150 \mathrm{~g}$ of MR powder/L. Male Holstein calves (3 to $5 \mathrm{~d}$ of age) from a single dairy farm were transported 3.5 $\mathrm{h}$ to the Nurture Research Center in southwest Ohio (Brookville). According to the farm's protocol, these calves had been fed $3 \mathrm{~L}$ of maternal colostrum at birth and again approximately $12 \mathrm{~h}$ after birth. After arrival calves were weighed (initial BW), blood was sampled from the jugular vein, serum was harvested, and serum protein concentration was immediately measured using an optical refractometer (Atago USA Inc., Bellevue, WA). At this time, calves were randomly assigned to treatments.

In trial 1a, 48 calves $(45 \pm 1.3 \mathrm{~kg}$ of initial BW) were fed a control starter with no added fat or oil (CON), a starter with $2 \%$ tallow (TAL), and a starter with $2 \%$ soybean oil (SBO; Table 1 ). Starters were $20 \%$ CP and 45 to $47 \%$ starch (Table 2). Calf ADG, hip width change, and starter intake were measured.

Trial $1 \mathrm{~b}$ was a subset of calves $(72 \pm 4.3 \mathrm{~kg}$ of initial BW) randomly selected from trial 1a to estimate the digestion of the diets. Chromic oxide was an indigestible digesta flow marker in the starters fed from d 46 to 56 . Chromic oxide was added to the starters to achieve an intake exceeding the minimum suggested $1 \mathrm{~g} /$ calf daily for digestibility estimates (Bouchard et al., 1973). Fecal samples were collected using rectal palpation for $5 \mathrm{~d}$ between d 52 and 56 . Fecal grab samples were frozen daily, combined on an equal wet weight basis, and then subsampled for analysis. Twelve fecal grab samples per calf were taken to account for 2-h intervals of the 24-h day by rotating sampling times over the 5 -d collection period.

Trial 2 used calves $(80 \pm 1.4 \mathrm{~kg}$ of initial BW) initially 59 to $61 \mathrm{~d}$ of age fed starters CON and SBO blended with $5 \%$ chopped grass hay over a 56 -d trial. Trial 3 used calves $(75 \pm 2.1 \mathrm{~kg}$ of initial BW) initially 59 to $61 \mathrm{~d}$ of age fed starters CON and TAL blended with $5 \%$ chopped grass hay over a $56-\mathrm{d}$ trial. Intake,
Table 1. Ingredient composition of dry feeds used in trials 1a, 1b, 2, and 3

\begin{tabular}{lccc}
\hline Ingredient, \% as-fed & Control & $\begin{array}{c}2 \% \\
\text { Tallow }\end{array}$ & $\begin{array}{c}2 \% \\
\text { Soy oil }\end{array}$ \\
\hline Corn, rolled coarse & 42 & 40 & 40 \\
Oats, whole & 20 & 20 & 20 \\
Molasses, cane & 3 & 3 & 3 \\
Tallow & 0 & 2 & 0 \\
Soy oil & 0 & 0 & 2 \\
Soybean meal, $48 \% \mathrm{CP}^{1}$ & 22.96 & 22.96 & 22.96 \\
Wheat middlings $^{1,2}$ & 7.2 & 7.2 & 7.2 \\
Starch $^{1}$ & 1.4 & 1.4 & 1.4 \\
Calcium carbonate $^{1}$ & 1.25 & 1.25 & 1.25 \\
Monocalcium phosphate $^{1}$ & 0.79 & 0.79 & 0.79 \\
Salt $^{1}$ & 0.6 & 0.6 & 0.6 \\
Vitamins, trace minerals $^{1,3}$ & 0.75 & 0.75 & 0.75 \\
Decoquinate, $60 \mathrm{~g} / \mathrm{kg}^{1,4}$ & 0.05 & 0.05 & 0.05 \\
\hline
\end{tabular}

${ }^{1}$ Included in a common pellet.

${ }^{2}$ In trial $1 \mathrm{~b}$, the diets were the same except that wheat middlings were $7.1 \%$ and chromic oxide was included at $0.1 \%$.

${ }^{3} 1.60 \mathrm{~g}$ of $\mathrm{Cu} / \mathrm{kg}, 0.13 \mathrm{~g}$ of $\mathrm{Co} / \mathrm{kg}, 9.40 \mathrm{~g}$ of Fe $/ \mathrm{kg}, 0.14 \mathrm{~g}$ of I/kg, $5.4 \mathrm{~g}$ of $\mathrm{Mn} / \mathrm{kg}, 0.04 \mathrm{~g}$ of $\mathrm{Se} / \mathrm{kg}, 6.70 \mathrm{~g}$ of $\mathrm{Zn} / \mathrm{kg}, 1,800 \mathrm{kIU}$ of vitamin $\mathrm{A} / \mathrm{kg}$, $600 \mathrm{kIU}$ of vitamin D/kg, $16 \mathrm{kIU}$ of vitamin E/ $\mathrm{kg}, 0.01 \mathrm{~g}$ of biotin/ $\mathrm{kg}$, $2.93 \mathrm{~g}$ of cobalamin $/ \mathrm{kg}, 0.04 \mathrm{~g}$ of folic acid $/ \mathrm{kg}, 1.77 \mathrm{~g}$ of niacin $/ \mathrm{kg}, 1.32$ $\mathrm{g}$ of pantothenic acid $/ \mathrm{kg}, 0.24 \mathrm{~g}$ of pyridoxine $/ \mathrm{kg}, 0.30 \mathrm{~g}$ of riboflavin/ $\mathrm{kg}, 0.29 \mathrm{~g}$ of thiamin/kg; Provimi North America, Brookville, OH.

${ }^{4}$ Zoetis, Florham Park, NJ.

ADG, change in hip width, and change in BCS were measured in each trial. An additive and a control treatment (unrelated to the present trials) were tested in these calves during their pre-weaning period and no differences in calf performance were detected. Calves had been randomized to the current treatments and the preweaning treatments.

Tallow was selected because it would not alter the concentrations of linoleic or linolenic acids in the feed. Soybean oil was selected because it is high in linoleic acid. Additions of the fat and oil were low $(2 \%)$ to reduce chances of reducing starter intake. Two percent soy oil was fed by Hill et al. (2011) to calves from 0 to 2 mo of age where it reduced ADG.

Each bag $(22.7 \mathrm{~kg})$ of MR and starter feed and every bale (approximately $22 \mathrm{~kg}$ ) of hay were sampled and composited before the initiation of the trials. Composites of feeds were analyzed (AOAC International, 2000) for DM (oven method 930.15), CP (Kjeldahl method 988.05), fat (alkaline treatment with Roese-Gottlieb method 932.06 for MR; diethyl ether extraction method 2003.05 for starters and hay), FA (GC method 963.22), and $\mathrm{Cr}$ (method 993.14). Additionally, the starter was analyzed for NDF with ash by the procedure of Van Soest et al. (1991) without sodium sulfite, and ADF with ash (Robertson and Van Soest, 1981). Compositions of the diets are in Table 1. Nutrient assays are in Tables 2 and 3. Each diet analyzed close to its formulated composition. 
Table 2. Analyzed nutrient composition of feeds in trials 1a, 2, and 3

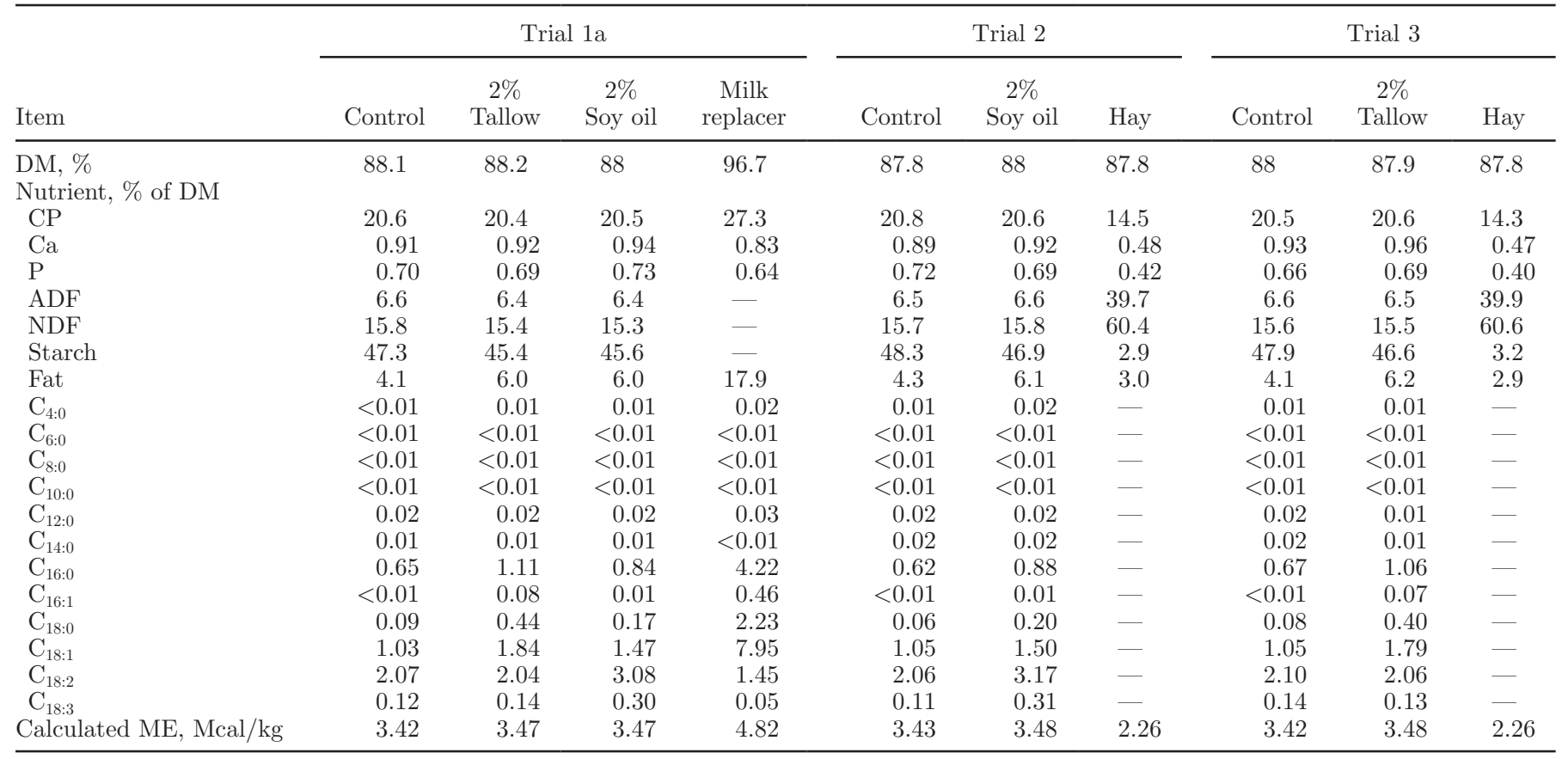

In trials $1 \mathrm{a}$ and $1 \mathrm{~b}$, calves were weighed every $7 \mathrm{~d}$ until the end of the trial (d 56). Dry feed offered and feed refusals were weighed daily. Fecal scores were assigned daily based on a 1-to- 5 system (1 being normal, thick in consistency; 2 being normal, but less thick; 3 being abnormally thin but not watery; 4 being watery; 5 being watery with abnormal coloring; modified from Kertz and Chester-Jones, 2004). Hip widths were measured with a caliper and BCS of calves were measured at d 0 and every $14 \mathrm{~d}$ thereafter. A 1-to-5 system with 0.25 unit increments was used for BCS $(1=$ emaciated to 5 = obese) based on a modification from Wildman et al. (1982). Scores were based on changes around the vertical and transverse processes of the spine as palpated by one experienced technician and ranged from 1.5 to 3.5. In trials 2 and 3 , calves were weighed, measured for hip width, and assigned a BCS initially and every $28 \mathrm{~d}$. Technicians were blind to treatments.

In trial $1 \mathrm{a}$ and $1 \mathrm{~b}$, calves were housed in 1.2- by 2.4$\mathrm{m}$ individual pens within a curtain sidewall barn with no added heat. The pens were bedded with long straw. Calves received an intranasal tissue-sensitive respiratory disease vaccine (TSV-2, Pfizer, Exton, PA) and subcutaneous injections of vitamins $\mathrm{A}, \mathrm{D}$, and $\mathrm{E}$ (Vital E - A + D, Schering-Plough Animal Health, Union, NJ) and Se (MU-SE, Schering-Plough Animal Health) upon arrival. Calves received an injection of Bovashield Gold 5 (Pfizer) at d 7 and again at d 28. Male calves were castrated and dehorned at $39 \mathrm{~d}$ of age. All medical treatments and protocols were under supervision of a veterinarian and were based on scouring (fecal scores $>2$ ), lethargy, elevated rectal temperatures, and rapid breathing.

In trials 2 and 3 , calves were housed in group pens with $6.5 \mathrm{~m}^{2}$ of outside pen space and $1.35 \mathrm{~m}^{2}$ of inside pen space per calf for the 56-d trials. The inside pen space was bedded with straw and there was no added heat. No animals were sick or were treated for sicknesses or vaccinated during the trials.

In trials $1 \mathrm{a}$ and $1 \mathrm{~b}$ the average nursery temperature was $5^{\circ} \mathrm{C}$ (ranged from -10 to $24^{\circ} \mathrm{C}$; cold stress) and average humidity was $68 \%$ (ranged from 30 to $99 \%$ ) based on hourly measurements. In trial 2 the average ambient temperature was $22^{\circ} \mathrm{C}$ (ranged from 10 to $36^{\circ} \mathrm{C}$; heat stress) and average humidity was $74 \%$ (ranged from 25 to $99 \%$ ) based on hourly measurements. In trial 3 the

Table 3. Analyzed nutrients in feeds from digestion estimates in trial $1 \mathrm{~b}$

\begin{tabular}{lccc}
\hline Item & Control & $\begin{array}{c}2 \% \\
\text { Tallow }\end{array}$ & $\begin{array}{c}2 \% \\
\text { Soy oil }\end{array}$ \\
\hline DM, \% & 88.2 & 88.3 & 88.2 \\
Nutrient, \% of DM & & & \\
CP & 20.5 & 20.6 & 20.6 \\
Ca & 0.90 & 0.90 & 0.92 \\
P & 0.69 & 0.71 & 0.71 \\
ADF & 6.7 & 6.5 & 6.5 \\
NDF & 15.6 & 15.5 & 15.6 \\
Fat & 4.2 & 6.1 & 6.0 \\
\hline
\end{tabular}


average ambient temperature was $-2^{\circ} \mathrm{C}$ (ranged from -18 to $17^{\circ} \mathrm{C}$; cold stress) and average humidity was $75 \%$ (ranged from 42 to $99 \%$ ) based on hourly measurements.

Data were analyzed using the MIXED procedure in SAS (ver. 8; SAS Institute Inc., Cary, NC) as a completely randomized design. The repeated measures mixed model was

$$
\mathrm{Y}_{\mathrm{ikl}}=\mu+\mathrm{T}_{\mathrm{i}}+\mathrm{W}_{\mathrm{k}}+\mathrm{TW}_{\mathrm{ik}}+\varepsilon_{\mathrm{ikl}},
$$

where $Y_{i k l}$ is the observed response, $T_{i}$ is the fixed effect of treatment $\mathrm{i}, \mathrm{W}_{\mathrm{k}}$ is the repeated effect of time $\mathrm{k}$ that was modeled as an auto-regressive type 1 covariance matrix within experimental unit, $\mathrm{TW}_{\mathrm{ik}}$ are the interactions of treatment $\mathrm{i}$ and time $\mathrm{k}$, and $\varepsilon_{\mathrm{ikl}}$ is error using the Kenward-Rogers procedures for determining the degrees of freedom. In trial $1 \mathrm{a}$ and $1 \mathrm{~b}$, where 3 treatments were used, the treatment means were separated using preplanned contrast statements (CON vs. TAL; CON vs. SBO). All data are reported as least squares means. The experimental unit was calf in trials $1 \mathrm{a}$ and $1 \mathrm{~b}$. The experimental unit was pen in trials 2 and 3. Statistical differences are discussed at $P<0.05$, whereas trends are mentioned when $P<0.1$.
RESULTS

\section{Trial 1a}

There were no differences $(P<0.1)$ in initial calf measurements (Table 4). No differences $(P<0.1)$ in preweaning calf performance were observed. Calves fed TAL tended $(P<0.1)$ to have lower feed efficiency than calves fed CON. Postweaning starter intake and calculated MR intake tended $(P<0.1)$ to be less for calves fed TAL than CON. Postweaning ADG was less $(P<0.05)$ for calves fed TAL than CON. Overall starter intake and ADG were less $(P<0.05)$ for calves fed TAL than CON. Days with abnormal fecal scores $(1.1 \pm 0.16 \mathrm{~d})$ and days treated for diarrhea $(2.4 \pm 0.32$ d) did not differ $(P>0.1)$ among treatments.

\section{Trial 1b}

During the 5-d collection period (d 52 to 56) intakes of DM, OM, CP, and Ca were less $(P<0.05)$ for calves fed SBO versus CON (Table 5). Intake of fat was less $(P<0.05)$ for calves fed CON versusTAL and SBO. Intake of DM per unit of BW did not differ $(P>0.05)$ among treatments. Digestibilities of DM, OM, and CP

Table 4. Intake and performance of calves initially 3 to $5 \mathrm{~d}$ of age that were fed 3 diets in Trial 1a

\begin{tabular}{|c|c|c|c|c|c|c|}
\hline Item & Control & $\begin{array}{c}2 \% \\
\text { Tallow }\end{array}$ & $\begin{array}{c}2 \% \\
\text { Soy oil }\end{array}$ & SEM & \multicolumn{2}{|c|}{$P$-value for contrast } \\
\hline Initial serum protein, $\mathrm{mg} / \mathrm{dL}$ & 4.7 & 4.8 & 4.6 & 0.14 & 0.59 & 0.67 \\
\hline Initial BW, kg & 44.6 & 45.1 & 44.3 & 1.3 & 0.95 & 0.79 \\
\hline Initial hip width, $\mathrm{cm}$ & 18 & 18 & 17.9 & 0.16 & 0.84 & 0.56 \\
\hline Milk replacer intake, $\mathrm{kg} / \mathrm{d}$ & 0.645 & 0.645 & 0.645 & - & - & - \\
\hline Starter intake, $\mathrm{kg} / \mathrm{d}$ & 0.198 & 0.19 & 0.195 & 0.02 & 0.78 & 0.91 \\
\hline ME intake, Mcal/d & 3.79 & 3.77 & 3.79 & 0.19 & 0.56 & 0.69 \\
\hline Feed efficiency ${ }^{1}$ & 0.555 & 0.502 & 0.521 & 0.025 & 0.08 & 0.36 \\
\hline \multicolumn{7}{|l|}{ Postweaning ( 42 to $56 \mathrm{~d}$ ) } \\
\hline $\mathrm{ADG}, \mathrm{kg} / \mathrm{d}$ & 0.661 & 0.682 & 0.604 & 0.028 & 0.8 & 0.06 \\
\hline $\mathrm{ADG}, \mathrm{kg} / \mathrm{d}$ & 0.565 & 0.551 & 0.521 & 0.017 & 0.26 & 0.04 \\
\hline Milk replaced intake, $\mathrm{kg} / \mathrm{d}$ & 0.323 & 0.323 & 0.323 & - & - & - \\
\hline Starter intake, $\mathrm{kg} / \mathrm{d}$ & 0.938 & 0.921 & 0.88 & 0.027 & 0.46 & 0.05 \\
\hline ME intake, Mcal/d & 4.76 & 4.75 & 4.61 & 0.13 & 0.26 & 0.19 \\
\hline Feed efficiency & 0.448 & 0.443 & 0.433 & 0.036 & 0.37 & 0.42 \\
\hline Hip width change, $\mathrm{cm}$ & 4.0 & 3.9 & 4.0 & 0.29 & 0.34 & 0.49 \\
\hline BCS change ${ }^{2}$ & 0.2 & 0.3 & 0.3 & 0.032 & 0.12 & 0.11 \\
\hline
\end{tabular}

${ }^{1}$ Gain divided by milk replacer plus starter intake.

${ }^{2} 1$-to-5 system based on Wildman et al. (1982). 
Table 5. Intake and apparent total-tract digestibility of nutrients fed 3 diets as determined from d 52 to 56 in trial $1 \mathrm{~b}$

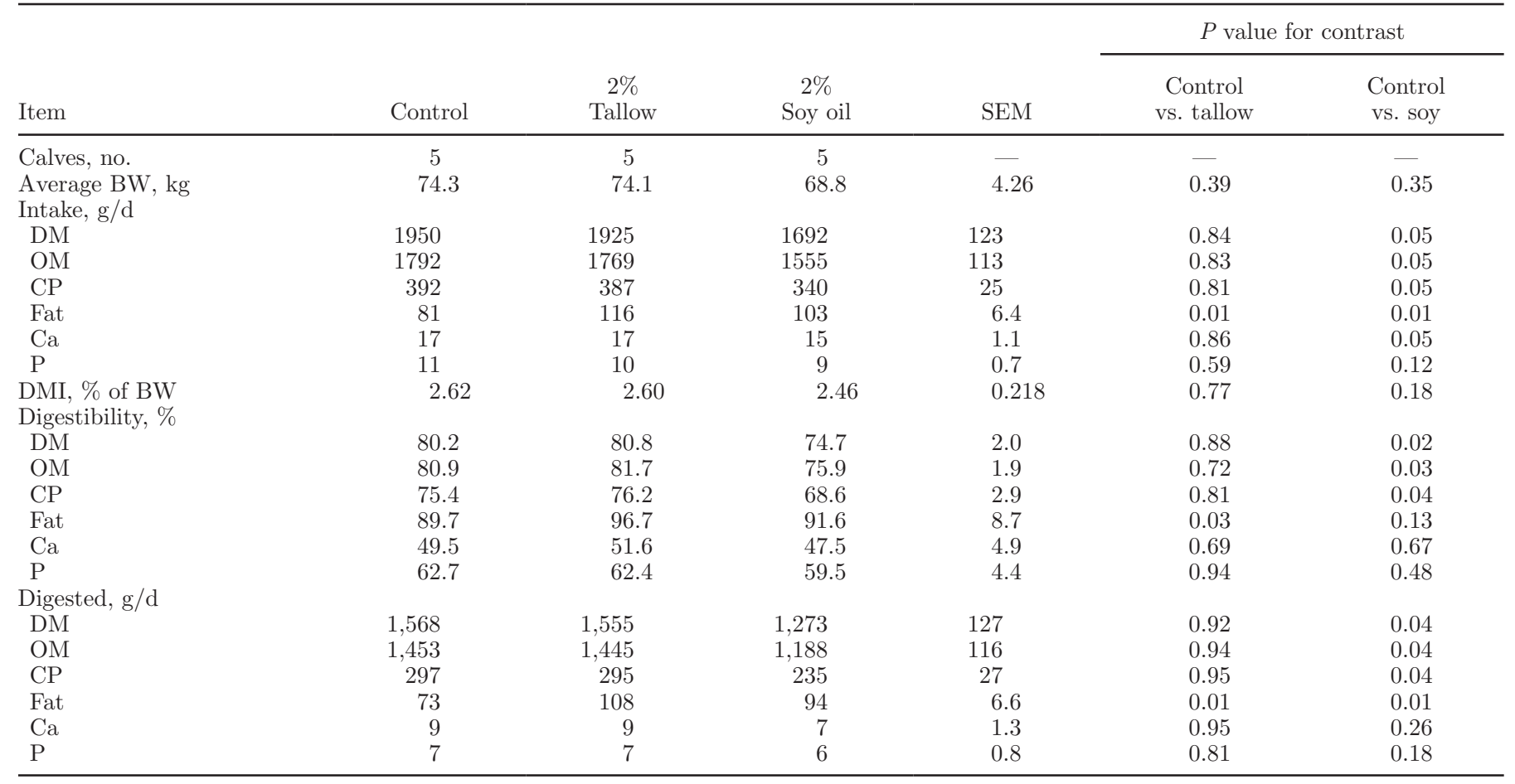

were less $(P<0.05)$ for calves fed SBO versus CON. Digestibility of fat was greater $(P<0.05)$ for calves fed TAL versus CON. The amounts of DM, OM, and CP digested daily were less $(P<0.05)$ for calves fed SBO versus $\mathrm{CON}$. The amounts of these nutrients digested were influenced by the lower BW of calves on SBO, resulting in a quantity of DMI (note that DMI per unit of BW did not differ by treatment). The amount of fat digested daily was more $(P<0.05)$ for calves fed SBO and TAL than CON.

\section{Trial 2}

Initial calf measurements did not differ $(P<0.1$; Table 6). Calves fed SBO had lower $(P<0.05)$ ADG and changes in hip widths than calves fed CON.

\section{Trial 3}

Initial calf measurements did not differ $(P<0.1$; Table 7). Calves fed TAL had lower $(P<0.05)$ ADG

Table 6. Intake and performance of calves initially 59 to $61 \mathrm{~d}$ of age that were fed 2 diets in trial 2

\begin{tabular}{|c|c|c|c|c|}
\hline Item & Control & $2 \%$ Soy oil & SEM & $P$ value \\
\hline Pens, no. & 6 & 6 & - & - \\
\hline Initial BW, $\mathrm{kg}$ & 79.0 & 80.6 & 1.37 & 0.43 \\
\hline Final BW, kg & 141.9 & 140.0 & 1.79 & 0.47 \\
\hline Initial hip width, $\mathrm{cm}$ & 22.1 & 22.2 & 0.14 & 0.40 \\
\hline Final hip width, cm & 28.5 & 28.0 & 0.18 & 0.11 \\
\hline Initial BCS & 2.5 & 2.5 & 0.04 & 0.56 \\
\hline Final BCS & 2.9 & 3.0 & 0.03 & 0.09 \\
\hline DMI, kg/d & 3.35 & 3.16 & 0.0770 & 0.11 \\
\hline DMI, \% BW & 3.08 & 2.91 & 0.081 & 0.16 \\
\hline ME intake, Mcal/d & 11.3 & 10.8 & 0.26 & 0.13 \\
\hline $\mathrm{ADG}, \mathrm{kg} / \mathrm{d}$ & 1.12 & 1.06 & 0.012 & 0.004 \\
\hline Feed efficiency, gain/feed & 0.338 & 0.340 & 0.0085 & 0.82 \\
\hline Hip width change, $\mathrm{cm}$ & 6.4 & 5.8 & 0.11 & 0.002 \\
\hline BCS change 1 & 0.4 & 0.5 & 0.03 & 0.01 \\
\hline
\end{tabular}

${ }^{1} 1$-to-5 system based on Wildman et al. (1982). 
Table 7. Intake and performance of calves initially 59 to $61 \mathrm{~d}$ of age that were fed 2 diets in trial 3

\begin{tabular}{lcccc}
\hline Item & Control & 2\% Tallow & SEM & $P$ value \\
\hline Pens, no. & 6 & 6 & - & - \\
Initial BW, kg & 76.7 & 73.3 & 2.12 & 0.28 \\
Final BW, kg & 138.2 & 130.5 & 2.20 & 0.03 \\
Initial hip width, cm & 22.0 & 21.4 & 0.26 & 0.13 \\
Final hip width, cm & 27.5 & 26.6 & 0.24 & 0.02 \\
Initial BCS & 2.5 & 2.4 & 0.04 & 0.05 \\
Final BCS & 2.9 & 2.8 & 0.02 & 0.001 \\
DMI, kg/d & 3.42 & 3.25 & 0.128 & 0.39 \\
DMI, \% BW & 3.23 & 3.24 & 0.085 & 0.97 \\
ME intake, Mcal/d & 11.5 & 11.1 & 0.28 & 0.37 \\
ADG, kg/d & 1.10 & 1.02 & 0.018 & 0.01 \\
Feed efficiency, gain/feed & 0.325 & 0.319 & 0.0092 & 0.66 \\
Hip width change, cm & 5.5 & 5.2 & 0.12 & 0.10 \\
BCS change & 0.4 & 0.4 & 0.06 & 0.97 \\
\hline
\end{tabular}

${ }^{1} 1$-to-5 system based on Wildman et al. (1982).

and tended $(P<0.1)$ to have less change in hip widths than calves fed CON.

\section{DISCUSSION}

Adding $2 \%$ tallow or $2 \%$ soy oil to the starters did not improve calf growth or ME intake. In fact, it reduced growth of calves from 2 to 4 mo of age in trials 2 and 3 and SBO reduced digestibility of DM, OM, and $\mathrm{CP}$ and $\mathrm{ADG}$ of calves less than 2 mo of age in trials $1 \mathrm{a}$ and $1 \mathrm{~b}$. The growth data in the current trials are consistent with Fallon et al. (1986), Caffrey et al. (1988), Doppenberg and Palmquist (1991), Kuehn et al. (1994), Bunting et al. (1996), and Hill et al. (2011), but inconsistent with Araujo et al. (2014). Araujo et al. (2014) suggested that their success with feeding fat in the starter was related to feeding a higher versus lower (approximately 0.69 vs. $0.46 \mathrm{~kg} / \mathrm{d}$ ) amount of MR. The $\mathrm{MR}$ in trials $1 \mathrm{a}$ and $1 \mathrm{~b}$ was fed at similar rates $(0.66$ vs. $0.44 \mathrm{~kg} / \mathrm{d}$ ) and had a similar composition to that of Araujo et al. (2014). Araujo et al. (2014) cited intake preference data of Montoro and Bach (2012), who reported the diet preferentially consumed by calves was $29 \% \mathrm{CP}$ and $6 \%$ fat, suggesting that calves may prefer a diet higher in fat than typically fed to calves. The high-fat diets in the current trials were $6 \%$ fat, whereas the high-fat diet of Araujo et al. (2014) was 11\% fat.

In calves fed only MR, excess fat has been reported to increase fattening (Tikofsky et al., 2001; Bascom et al., 2007) while reducing muscle and frame growth (Bascom et al., 2007). We observed similar responses, as added fat reduced hip width change and increased BCS change in trial 2 , tended to reduce hip width change in trial 3, and reduced ADG in both trials.

In trial $1 b$, fat digestibility (\% and amount) of calves fed TAL was greater than CON, but fat digestibility of SBO and CON were not different. Araujo et al. (2014) reported fat digestibility (\%) of their high-fat treatment from soybeans to be greater than their low-fat treatment. In trial $1 \mathrm{~b}, \mathrm{DM}, \mathrm{OM}$, and $\mathrm{CP}$ digestibility (\% and amount) of calves fed SBO was less than calves fed CON, the opposite of what Araujo et al. (2014) reported for $\mathrm{CP}(\%)$, whereas DM digestibility did not differ between treatments. These discrepancies for digestibility and previously mentioned ADG between the trials and laboratories are not clearly discernible. Initial age of the calves was different from those in Araujo et al. (2014), with our calves being approximately $1 \mathrm{wk}$ younger.

In trial $1 \mathrm{~b}, \mathrm{Ca}$ and $\mathrm{P}$ digestibility was not changed in the weaned calf when fat was increased from 4 to $6 \%$, whereas digestibility of $\mathrm{DM}, \mathrm{OM}$, and $\mathrm{CP}$ was decreased. Increasing fat in an MR has reduced digestibility of Ca and P (Toullec et al., 1980; Hill et al., 2009). Increasing fat in a dry diet has reduced digestibility of $\mathrm{Ca}$ and $\mathrm{P}$ in other species as well (French and Elliot, 1943; Calverley and Kennedy, 1949). All of these trials tested fat increases of more than the $2 \%$ unit increase in trial $1 b$.

\section{CONCLUSIONS}

Including $2 \%$ tallow or soybean oil in calf starters fed to calves from near birth to 4 mo of age was not effective at increasing calf growth or ME intake. In fact, it reduced growth of calves from 2 to 4 mo of age in trials 2 and 3 and $2 \%$ soybean oil reduced digestibility of DM, $\mathrm{OM}$, and $\mathrm{CP}$ and ADG of calves less than 2 mo. These results are consistent with most of the published data.

\section{REFERENCES}

AOAC International. 2000. Official Methods of Analysis. Vol. 1. 17th ed. AOAC International, Arlington, VA. 
Araujo, G., M. Terré, and A. Bach. 2014. Interaction between milk allowance and fat content of the starter feed on performance of Holstein calves. J. Dairy Sci. 97:6511-6518.

Bascom, S. A., R. E. James, M. L. McGilliard, and M. Van Amburgh. 2007. Influence of dietary fat and protein on body composition of Jersey bull calves. J. Dairy Sci. 90:5600-5609.

Bouchard, R., G. J. Brisson, and J. P. Julien. 1973. Nutritive value of bacterial sludge and whey powders for protein in calf milk replacers and on chromic oxide as indicator of digestibility. J. Dairy Sci. 56:1445-1449

Bunting, L. D., J. M. Fernandez, R. J. Fornea, T. W. White, M. A Froetschel, J. D. Stone, and K. Ingawa. 1996. Seasonal effects of supplemental fat or undegradable protein on growth and metabolism of Holstein calves. J. Dairy Sci. 79:1611-1620.

Caffrey, P. J., C. Mill, P. O. Brophy, and D. L. Kelleher. 1988. The effects of method of processing of starters, tallow inclusion and roughage supplementation on the performance of early-weaned calves. Anim. Feed Sci. Technol. 19:231-246.

Calverley, C. E., and C. Kennedy. 1949. The effect of fat on calcium and phosphorus metabolism in normal growing rats under a normal dietary regime. J. Nutr. 38:165-175.

Doppenberg, J., and D. L. Palmquist. 1991. Effect of dietary fat level on feed intake, growth, plasma metabolites and hormones of calves fed dry or liquid diets. Livest. Prod. Sci. 29:151-166.

Fallon, R. J., P. E. V. Williams, and G. M. Innes. 1986. The effects on feed intake, growth and digestibility of nutrients of including calcium soaps of fat in diets for young calves. Anim. Feed Sci. Technol. 12:103-115

FASS. 2010. Guide for the Care and Use of Agricultural Animals in Research and Teaching. 3rd ed. Federation of Animal Science Societies, Savoy, IL.

French, C. E., and R. F. Elliot. 1943. The interrelation of calcium and fat utilization. J. Nutr. 25:17-21.
Hill, T. M., H. G. Bateman II, J. M. Aldrich, and R. L. Schlotterbeck. 2009. Effects of fat concentration of a high protein milk replacer on calf performance. J. Dairy Sci. 92:5147-5153.

Hill, T. M., H. G. Bateman II, J. M. Aldrich, and R. L. Schlotterbeck. 2011. Impact of various fatty acids on dairy calf performance. Prof. Anim. Sci. 27:167-175.

Kertz, A. F., and H. Chester-Jones. 2004. Invited review: Guidelines for measuring and reporting calf and heifer experimental data. J Dairy Sci. 87:3577-3580.

Kuehn, C. S., D. E. Otterby, J. G. Linn, W. G. Olson, H. ChesterJones, G. D. Marx, and J. A. Barmore. 1994. The effect of dietary energy concentration on calf performance. J. Dairy Sci. $77: 2621-2629$.

Montoro, C., and A. Bach. 2012. Voluntary selection of starter feed ingredients offered separately to nursing calves. Livest. Sci. 149:6269.

Robertson, J. B., and P. J. Van Soest. 1981. The Detergent System of Analysis and its Application to Human Foods. Cornell University, Ithaca, NY.

Tikofsky, J. N., M. E. Van Amburgh, and D. A. Ross. 2001. Effect of varying carbohydrate and fat content of milk replacer on body composition of Holstein bull calves. J. Anim. Sci. 79:2260-2267.

Toullec, R., M. Theriez, and P. Thivend. 1980. Milk replacers for calves and lambs. World Anim. Rev. 33:32-42.

Van Soest, P. J., J. B. Robertson, and B. A. Lewis. 1991. Methods for dietary fiber, neutral detergent fiber, non-starch polysaccharides in relation to animal nutrition. Symposium: Carbohydrate methodology, metabolism and nutritional implications in dairy cattle. J. Dairy Sci. 74:3583-3597.

Wildman, E. E., G. M. Jones, P. E. Wagner, R. L. Bowman, H. F. Troutt Jr., and T. N. Lesch. 1982. A dairy cow body condition scoring system and its relationship to selected production characteristics. J. Dairy Sci. 65:495-501. 